THE UNFOLDING OF ARTISTIC ACTIVITY 



\section{THE UNFOLDING OF}

ARTISTIC ACTIVITY

Its Basis, Processes, and Implications

\section{BY HENRY SCHAEFER-SIMMERN}

WITH A FOREWORD BY JOHN DEWEY

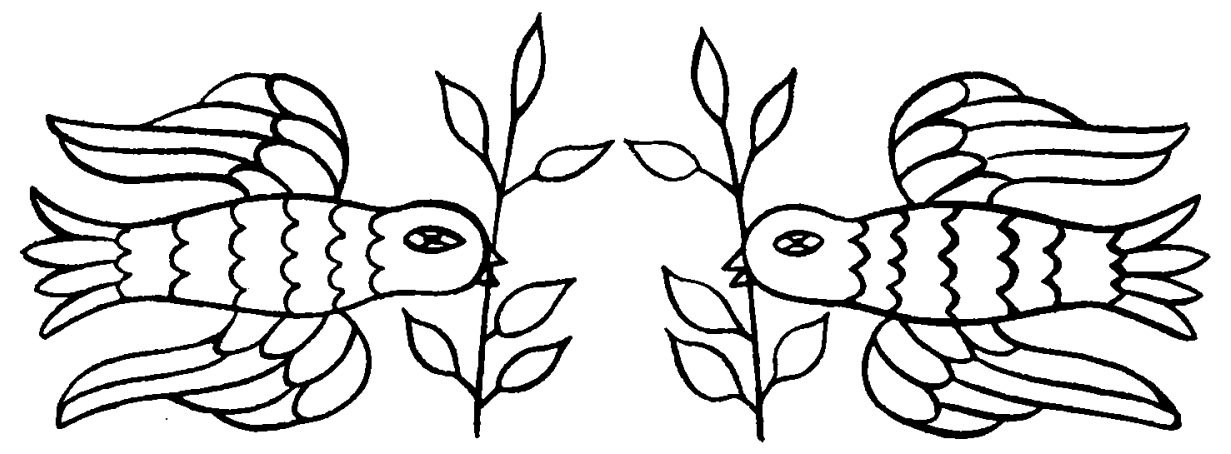

UNIVERSITY OF CALIFORNIA PRESS BERKELEY LOS ANGELES LONDON 
UNIVERSITY OF CALIFORNIA PRESS

BERKELEY AND LOS ANGELES

CALIFORNIA

$\infty$

CAMBRIDGE UNIVERSITY PRESS LONDON, ENGLAND

COPYRIGHT, I 948 , BY

THE REGENTS OF THE UNIVERSITY OF CALIFORNIA

PRINTED IN THE UNITED STATES OF AMERICA

567890 
TO THE MEMORY OF GUSTAF BRITSCH

$1879-1923$ 



\section{FOREWORD}

HE CONTRIBUTION made in this volume to the
philosopbies of art and of education is notable from
the standpoint of theory. At the same time, I believe
that, important as is the contribution to both of these subjects, there is anotber one that is its most distinguished trait. It is that upon which emphasis falls in these introductory remarks. The principles in question are taken out of and beyond the territory of theoretical philosophy into the field of demonstrated fact. I shall, of course, bave to confine what I say to the principles. But I should not be faithful to the book itself if I did not give first and foremost place to their testing and confirmation in work carried on over many years and with a variety of groups. This demonstration, reported in words and in pictorial evidence, gives substance and form to the principles that are set forth.

The first of the principles to which I would call attention is the emphasis upon individuality as the creative factor in life's experiences. An immense amount bas been said and written about the individual and about individuality. Too much of it, however, is vitiated by setting up what these words stand for as if it were something complete in itself in isolation. Here, it is seen and consistently treated as the life factor that varies from the previously given order, and that in varying transforms in some measure that from which it departs, even in the very act of receiving and using it. This creativity is the meaning of artistic activity-which is manifested not just in what are regarded as the fine arts, but in all forms of life that are not tied down to what is establisbed by custom and convention. In re-creating them in its own way it brings refreshment, growth, and satisfying joy to one who participates.

Accompanying this principle, or ratber inseparable from it, is the evidence that artistic activity is an undivided union of factors which, when separated, are called physical, emotional, intellectual, and practical-these last in the sense of doing and making. These last, bowever, are no more routine and dull than the emotional stir is raw excitation. Intelligence is the informing and 
formative factor throughout. It is manifested in that keen and lively participation of the sense organs in which they are truly organs of constructive imagination. Intelligence is also manifested in the organizing activity of which aestbetic form is the result. But notbing could be further away from that conformity to fixed rules, disguised as principles and standards, which is too often taken to be the function of "rationality." Escape from the onesidedness which attends many philosopbies of sense, of reason, of bodily or physical action, of emotion, and of doing and making, distinguishes the work reported upon in the following pages. In their place there is constant observation of the wholeness of life and personality in wbich activity becomes artistic.

Because of this wholeness of artistic activity, because the entire personality comes into play, artistic activity which is art itself is not an indulgence but is refreshing and restorative, as is always the wholeness that is bealth. There is no inberent difference between fullness of activity and artistic activity; the latter is one with being fully alive. Hence, it is not sometbing possessed by a few persons and setting them apart from the rest of mankind, but is the normal or natural buman beritage. Its spontaneity is not a gush, but is the naturalness proper to all organized energies of the live creature. Persons differ greatly in their respective measures. But there is something the matter, something abnormal, when a buman being is forbidden by external conditions from engaging in that fullness according to bis own measure, and when be finds it diverted by these conditions into unbealt by physical excitement and appetitive indulgence.

Normally and naturally, artistic activity is the way in which one may "gain in the strength and stature, the belief in bis own powers, and the self-respect, which make artistic activity constructive in the growth of personality." It is this fact that distinguishes the demonstrations conducted by Professor Schaefer-Simmern. They take place in a particular field of activity as every form of experimental demonstration must do. But tbrough that field, as well as in it, there is convincing thoronghgoing demonstration that activity which is artistic extends beyond all subjects conventionally named "The Fine Arts." For it provides the pattern and model of the full and free growtb of personality and of full life activity, wherever it occurs, bringing refreshment and, when needed, restoration.

I am glad accordingly to close as I began-upon the note of effective demonstration of what is sound and alive in theoretical pbilosophies of art and of education. 


\section{PREFACE}

IN THE last quarter of the nineteentb century, the decline of artistic culture in central Europe impelled a few valuable attempts at definition of the basic meaning of artistic activity and of its realization in works of art. Conrad Fiedler, one of the great patrons of the time, concluded that "artistic activity begins when man, driven by an inner necessity, grasps with the power of his mind the entangled multiplicity of appearances and develops it into configurated visual existence." This is common knowledge to all genuine artists, from their daily experience; yet in official art education it has been almost unknown and very seldom applied. It is to the merit of the late Gustaf Britsch that be verified Fiedler's ideas scientifically in his Theorie der bildenden Kunst. He shows that artistic activity as a "general attribute of the buman mind" reveals itself, to a modest degree, in children's untutored drawings as well as in beginning stages of art of all times. He demonstrates the existence of definite evolutionary stages by which artistic configuration develops gradually from simple to more complex relationships of form. Thus be indicates a way toward the foundation of an art education which will encourage the natural unfolding of artistic activity as an inberent quality of man.

Mywork in art education bas been decisively stimulated by Britsch's theory. For twenty years I bave tested his principles in practice, with children and adults, persons of different nationalities and of different mental, educational, and economic backgrounds. I bave extended bis theory and added to bis findings. Out of this experience a doctrine of art education bas emerged which may serve as a stimulus for new educational procedures and may activate latent, bitherto unconsidered, potentialities in artistic as well as other fields of buman functioning. Moreover, sucb broadening of the layman's capabilities bas definite social and cultural implications.

It seemed a natural step in the promotion of these ideas that they should find their first decisive American support in an organization dedicated to the "improvement of social and living conditions," the Russell Sage Foundation 
in New York City. This book presents the results of an experiment undertaken and financed by the Foundation for the purpose of showing by actual case bistories the development of the creative potentialities in men and women in business and the professions, and in institutionalized delinquents and mental defectives; that is, in persons not devoted to the arts.

In presenting the artistic developments of various participants I was faced with the task of expressing by conceptual, verbal terms what bad been experienced visually, and of arranging successively and logically factors which in reality were simultaneous and interrelated.I may, therefore, sometimes speak a language unfamiliar to the artist, to whom the artistic process is a well-known fact; and to the layman I may even speak of a process unknown to bim, and in a language to which be is not accustomed. But these departures seem unavoidable in written statements like the present one. Knowing a picture from verbal description and grasping the picture visually are two completely different experiences. I should like to caution the reader against the rejection of unfamiliar concepts which stand for unfamiliar ideas. The important tbing is to understand the processes for which the unfamiliar words are mere symbols.

I am greatly indebted to Dr. Allen Eaton, Director of the Department of Arts and Social Work of the Russell Sage Foundation. It was be who first saw the social implications of my work and prepared the way for introducing my experiment into the activities of the Foundation. He belped to organize the different projects, and throughout the four and a balf years of my association with his department be was always generous with bis advice. His constant belief in the ultimate value of what I was doing has contributed decisively to the final outcome. I also feel grateful to Dr. Shelby M. Harrison, General Director of the Russell Sage Foundation, whose approval made the experiment possible. I wish to thank Mr. Frederick R. Sacher, Superintendent of the New York City Reformatory in New Hampton, New York, and Mr. Ernest $N$. Roselle, Superintendent of the Soutbbury Training Scbool in Soutbbury, Connecticut, for their permission to carry out this experiment in their institutions, and for their coöperation. I am grateful to Dr. Seymour Sarason, Chief Psychologist of the Soutbbury Training School and Assistant Professor of Psychology in Yale University, for his active participation and bis report on bis observations. To Dr. Rudolf Arnbeim, of Sarab Lawrence College, I extend my sincere appreciation for suggestions that belped to clarify the psychological aspects of my work. I express my gratitude to Dr. Esther Lucile 
Brown, Director of the Department of Studies on Professions of the Russell Sage Foundation, for belping to shape the manuscript. For invaluable advice and criticism I owe much to Dr. Martin Scbütze, professor emeritus of the University of Cbicago. To Professor Jobn Dewey I can only very inadequately voice my thanks for the Foreword which be has so generously supplied. Finally, I wish to thank all my students, who created the material for this book.

University of California,

H. S.-S.

Berkeley, December, 1947. 


\section{ADDENDUM, 1961}

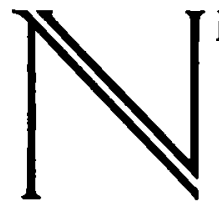

EARLY twelve years bave passed since the first printing of this book. In the meantime, basic changes in the theory and practice of visual art that bave been developing for several decades have become accepted contemporary trends. Some of the pictorial results are said to manifest "the free expression of the self," or the intuitive emergence of the artist's subconscious, or even to be visualizations of personal mystical revelations over which the artist has no control. Others do not pretend to be more than the display of emotional experiences. For the understanding and interpretation of any of these efforts, one can use only psychological and metaphysical approaches. Certain pictorial aspirations are affected by the new scientific discoveries and the corresponding new philosophical worldoutlooks. To understand and interpret them, one must first of all grasp the scientific or pbilosophical suppositions which inspired them; but this means leaving the realm of visual perception, the true world of visual art, even if one intends later to return to it. Still other contemporary art trends seek status by the exaltation of one or another of the pictorial means pertaining to the artistic structure; they try for new discoveries in art by playful experimentalizing with line, mass, colors, planes; it is here that one finds "investigations into the spatial meaning of planes," and pictorial efforts that are said to exemplify "new theories of optics." And yet further, "there are twenty different systems or methods of abstract art" alone. And "action painting" finds the significance of its works in the plastic realization of the artist's psycho-physical powers; his courage and bis domination over bis world are supposedly reflected in bis forceful brushstrokes and large canvases. Finally, there should be mentioned the attempts of modern art education to bring about the creation of something new by teaching ready-made, rationalized principles and rules of composition that lead to pictorial unifications quite external to the "creator." To understand and to do justice to the

\footnotetext{
${ }^{1}$ Michel Seuphor, Dictionary of Abstract Painting (New York: Tudor Publishing Co., 1957), p. 10.
}

$$
\{x i v\}
$$


meaning of such results, a knowledge of the underlying art-educational theory is required.

Obviously, a theory of art and art education which is concerned with the unfolding and development of an artistic language of form as an inberent mental attribute of every normal buman being bas notbing to offer to the interpretation of sucb pictorial results as have been mentioned above. The present-day trends rest upon ideologies, and stress approaches, with which the ideas set forth in this volume are substantially uncongenial. It is impossible to employ the ideas bere presented if one is to give meaning to artistic phenomena so beterogeneous. And, vice versa, any attempt to approach the substance of this book from concepts of art and art education essentially alien to its intrinsic nature must inevitably misinterpret its meaning and importance. A distinct separation between the attitudes of today's art trends and the ideas presented bere seems unavoidable if one is to assess either the one or the other at its proper value.

Those opponents of my ideas in art education who refuse to recognize them because they lack conformity with any contemporary theories of art should perbaps be reminded that I consider "education" still in its original meaning as "leading or drawing out" and not as "stuffing in." This educational attitude of mine-especially concerning art education-is substantiated by Gustaf Britsch's Theorie der bildenden Kunst, which gives insights into the natural development of that mental faculty of man that enables bim spontaneously to create interfunctional relationships of form in the realm of pure vision, independent of abstract rational thinking or of superimposed guidance. Only on this basis may the layman produce artistically in terms of bis true nature. It would be difficult, if not impossible, to find in any of the theories underlying contemporary art trends the mental basis for such creativity.

It should thus be clear that any attempt to "teach" the layman according to the rules of present-day art movements will be unsound artistically as well as educationally. In the course of my thirty-five years in the field of art education I bave seen over and over again the disastrous effects of teachingmethods, aiming mainly at external production, which resort to current notions with which the student's own artistic conceptions are little or not at all congenial. In fact sucb influences are likely to bring forward individuals, split mentally and emotionally, whose inner lack of security is armored 
in the triple brass of an arrogance that for them is protective but to others is insufferable. Instead of being in full accord with their work, they are subjected to great nervous tensions. This, of course, stands in utter contrast to the purposes of the present volume. The mental, emotional, and physical synthesis of man, bis bealthy functional wholeness, is the final aim of my educational efforts. Only that kind of art activity which is intrinsically related to man's nature can serve that aim.

My work with lay students bas frequently been criticized because it lacks a bent toward nonobjective art, which to my critics is "the only art that symbolizes the mind of contemporary man." It bas been said in justification of the works of those artists who produce nonobjective art that the world, so far as they are concerned, is "irrevocably exbausted"; but it is not thus exbausted for the layman. Though bis artistic vision is stimulated by the objects of the visible world, the beginnings of bis artistic activity, regardless of how simple they may be, are not imitative, not merely expressive, but creative in the sense of producing spontaneously an interfunctional, selfsustained relationship of form. Similarly as in the artistic productions of primitive man, in genuine folk art, and in the unadulterated pictorial activity of children, "the essence of the world which be tries to appropriate mentally and to subjugate to himself consists in the visible and tangible Gestalt-formation of its objects." To bim, "art does not start from abstract thought in order to arrive at forms; rather it climbs from the formless to the formed, and in this process is found its entire mental meaning." There is no need of introducing to the layman anotber approach for bis pictorial activity when already bis innate, spontaneous approach can be basically creative.

I have repeatedly been accused of deliberately cultivating an artistic primitivism, and this in a bighly sophisticated world that is everywbere dominated by scientific investigations. My critics seem to bave forgotten that my entire art-educational program is built upon the idea of "the unfolding of artistic activity" and not upon the teaching of ready-made formulas for the fabrication of works of art. "Unfolding," bowever, can only start from a primary state of being from which a gradual development can take place

\footnotetext{
'Conrad Fiedler, On Judging Works of Visual Art (2d ed.; University of California Press, 1957), p. 43. Fiedler is here speaking of "the artist"; but what he has to say applies also to "the layman" in the sense proper to the present discussion.

I Ibid., p. 49 .
} 
in accordance with definite stages of growth. Primary, primitive, stages within artistic unfolding are therefore not only indispensable, but are the only guarantee of a normal, natural growth of that activity. The inborn creative potentialities of many persons are of course limited; these individuals may remain always in primary states of artistic awareness. There is notbing wrong with this. Their primary, primitive, artistic achievements are the natural outcome of their talents, and are bumanly and artistically genuine. The artistic language of the people bas always been a primary one in comparison with the artistic language of the masters; nevertbeless, it bas always been the backbone of the artistic culture of the people. The apparent structural similarity in the beginning of visual configurations in the artistic productions of laymen is due to an undifferentiated way of visually conceiving relationships of form. With more differentiation of these relationships, more differentiated structures appear and more individual expression becomes possible. This phenomenon can be plainly seen in the development of art in all epochs as well as in primitive and folk art.

In some references to my work as presented in this book it bas been stated that I am fostering "visual memory" in order to make possible the attainment of visual configuration. This is a basic misinterpretation of my ideas. The cause of the misleading statement lies in practices common to presentday art education, practices that derive from the illusion that interfunctional relationships of form - visual configuration - can be attained by urging the student to "reproduce the visually present subject," and that "ultimately be becomes creatively productive only when be is able to call forth, from memory, a visual "configuration' to serve bis expressive purposes." Nowbere in this volume has such a practice ever been mentioned. It is the misinterpretation that needs a thorough clarification.

$V$ isual memory tries to remember (indeed, to "re-member") the external shapes of objects in a piecemeal way. Asking how this or that part of the object may look, bow it may be connected with other parts, bow large or small, thick or thin it may be, in what proportions it stands to its surroundings, calls for the belp of rational calculation, and not for visual conceiving. In so doing it puts parts of objects together without any interfunctional relationship of the shapes to each otber. The outcome is a "remembering," a putting together of disjunct members, isolated details; parts

\footnotetext{
'Frederick M. Logan, Growth of Art in American Scbools (New York: Harper \& Brothers, 1955), p. 257.
} 
can be changed without affecting the whole. Such weak structures, arranged willfully in order to re-collect various members of objects, can never lead to the establishment of visual configurations. The drawing of a tree bere illustrated in picture $A$ is an example of an image resulting from visual memory. Just the opposite is shown in picture $B ;^{5}$ the wbole structure of this drawing
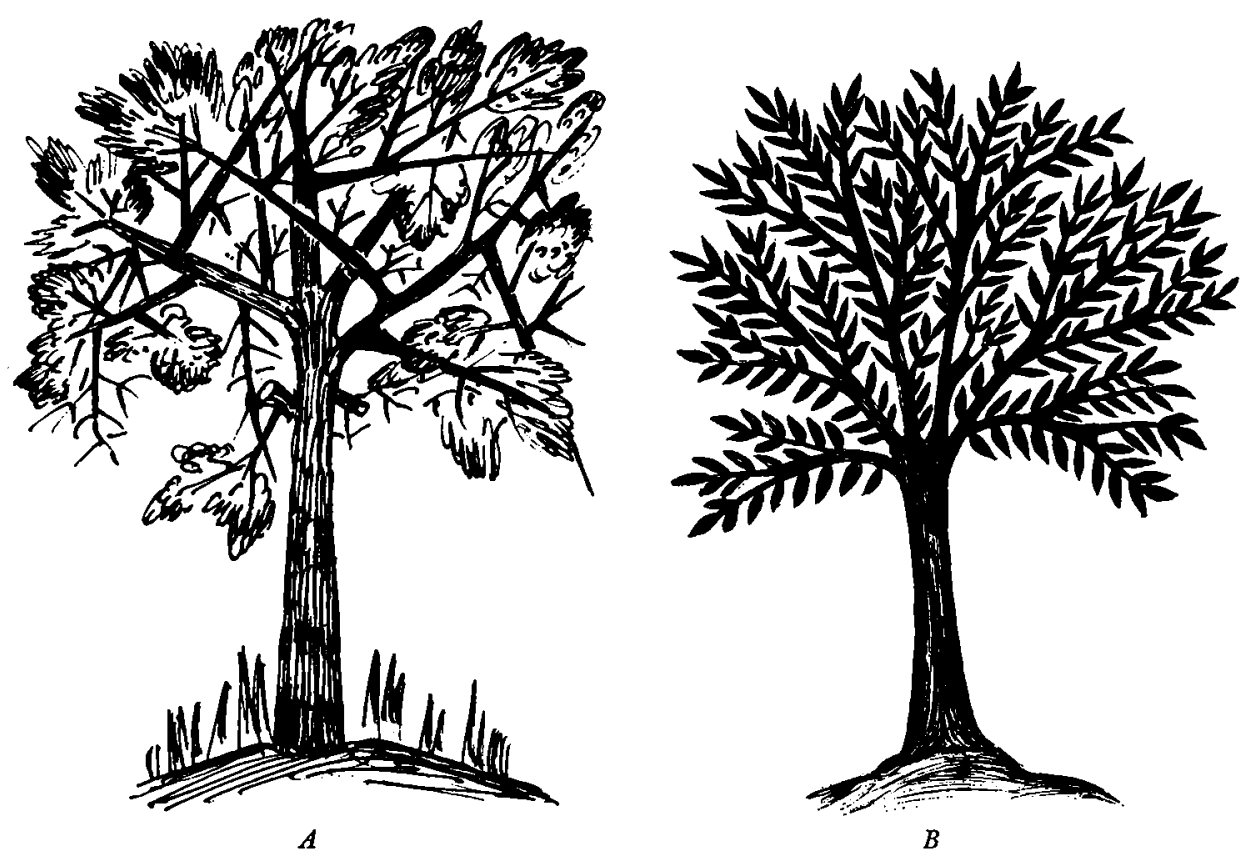

of a tree reveals a definite visual order in the relationship of all parts to each other. First, the whole tree and all its details are set of from the empty white background, and thus the drawing attains a unified flatness all over. Further, the main shape, consisting of tree trunk and large and smaller branches, discloses a visual pattern built upon a relationship of definite slanting angles that determine also the relationship of leaves to twigs; and thus one direction of lines leads into the direction of lines adjoining, so that the eye of the observer is guided to grasp the total image. If a change is undertaken in any part, either in the relationship of the figure to its empty background or in the definite relationship of the directions of the slanting lines, the whole drawing loses the particular quality of its configuration.

By now it should be clear that such a self-sustained unity of form-relation-

\footnotetext{
"It should be noted that this example represents only one particular stage of visual configuration corresponding to an early stage of artistic development.
} 
ships can never be the result of visual memory. Ratber, one is compelled to recognize that specific power in the mind of man by virtue of which be is able to create such a configuration of form-the artistic form-wbich in turn leads to the artistic interpretation. The spontaneous creation of the artistic form, its unfolding and development as an intrinsic attribute of every normal buman being, is the very substance of this volume.

I should like to express my gratitude to Dr. Rudolf Arnbeim of Sarab Lawrence College, who is also Professor of Psychology at the New School for Social Research, and to Dr. Seymour Sarason, Professor of Psychology at $Y$ ale University, both of whom bave generously referred to the importance of my work in their own publications. To all art educators who bave used this book as an inspiration for their endeavors-making this third printing necessary - I bumbly voice my thankfulness.

H. S.-S.

Berkeley, California,

March, 196 . 
